\title{
Drugs Shown to Inhibit SARS-CoV-2 in COVID-19 Disease: Comparative Basic and Clinical Pharmacology of Molnupiravir and Ivermectin
}

\begin{abstract}
Ajayi AAL*
Department of Medicine, Division of Hypertension and Clinical Pharmacology, Baylor College of Medicine, USA *Corresponding author: Ajayi AAL, Department of Medicine, Division of Hypertension and Clinical Pharmacology, Baylor College of Medicine, Houston TX 77030, USA
\end{abstract}

Received: July 10, 2021; Accepted: August 03, 2021; Published: August 10, 2021

\begin{abstract}
The pharmacology of anti-SARS-CoV-2 drugs, Molnupiravir (M) and repurposed Ivermectin (IV) were compared. The $\mathrm{IC}_{50}$ for the inhibition of viral replication were $0.3 \mu \mathrm{M}$ for $\mathrm{M}$ and $2.8 \mu \mathrm{M}$ for IV. Both drugs have good oral absorption, with $\mathrm{M}$ achieving peak plasma concentrations by 2 hours and IV by 5 hours. The plasma half life were 7 hours for $M$ and 81-91 hours for IV. M inhibits viral replication inducing viral mutagenesis in RdRp, causing viral error catastrophe and viral extinction. IV affects viral cell entry, nuclear transport and inhibits replication via RdRp. IV has additional effect to suppress cytokine production through STAT-3 inhibition. M is a more potent antiviral drug and IV has a longer residence in the body. Their effects on RdRp and cytokine inhibition are potentially complimentary for anti-COVID-19 activity. Both IV and M should be compared in randomized controlled clinical trials, and the possibility of their combination for anti-SARS-CoV-2 antiviral actions, explored further.
\end{abstract}

Keywords: COVID-19; Antiviral therapeutics; Molnupiravir; Ivermectin; Combination

\section{Introduction}

The COVID-19 pandemic caused by SARS-CoV-2, has affected more than 120 million people and resulted in nearly 3 million deaths worldwide. Although vaccine roll out is mitigating the community transmission and enabling a reopening of global economy piecemeal, there are still many nations where vaccines are not yet widely available, and new viral variants are emerging. There is a gradual shift in focus, to antiviral drugs, both for possible adjunctive chemoprophylaxis, as well as for active treatment of patients with new SARS-CoV-2 infections, or post -vaccination breakthrough COVID-19 cases. There have been purposive efforts, to develop novel and specific antiviral drugs for SARS-CoV-2, and to repurpose existing FDA -approved drugs to treat COVID-19. Molnupiravir is the most advanced of the novel antiviral drugs undergoing clinical development and trials, whilst Ivermectin is the most studied "repurposed" medication globally, in randomized clinical trials, retrospective studies and metaanalyses. This mini- review examines and compares their basic and clinical pharmacology and the possible utility of their combination, in treating COVID-19 and future corona virus diseases.

Molnupiravir and Ivermectin Anti-SARSCoV-2 Mechanisms, Pharmacokinetics and Pharmacodynamics

Molnupiravir (EIDD2801/MK-4482) is a pro-drug of the novel active antiviral nucleoside analogue $\beta$-d-N4-hydroxycytidine (NHC, EIDD1931) [1]. It's a broad spectrum antiviral agent against SARSCoV-2, SARS-CoV,seasonal or pandemic influenza and MERS corona virus [1]. The basic and clinical pharmacological properties are shown on Table 1. Ivermectin is an FDA-approved, WHO essential drug used as broad spectrum antiparasitic, antibiotic and which has demonstrated broad spectrum antiviral activity against RNA viruses, including HIV, Zika, MERS corona virus. It is being repurposed as a therapeutic agent for COVID-19, after in vitro studies in Vero/hSLAM cells, showed that it caused a 5000-fold inhibition of SARS-CoV-2, (99.98\% at 48 hours) with an IC50 of $2.8 \mu \mathrm{M}$ [2]. The corresponding in vitro $\mathrm{IC}_{50}$ of molnupiravir for SARS-CoV-2 is $0.3 \mu \mathrm{M}$ in Vero cells and $0.08 \mu \mathrm{M}$ in Calu-3 Cells [3]. The $\mathrm{IC}_{50}$ of Molnupiravir shows it to be a more potent anti-SARS-CoV-2 agent, compared to Ivermectin in vitro. Both molnupiravir and ivermectin are well absorbed after oral dosing, the Tmax of molnupiravir being 1-1.75 hours, with a half life of 7 hours, 1 whilst the Tmax of ivermectin is 4-6 hours, and a very long half life of 81-91 hours [4]. Ivermectin, being lipophilic has a large volume of distribution $\left(\mathrm{V}_{\mathrm{d}}\right)$ and the ability to accumulate in the lungs [5], the major target organ of COVID-19. Molnupiravir is given twice daily, and doses of 400 and $800 \mathrm{mg}$ showed viral clearance by RT-PCR [1]. By contrast, the dosing regimen of ivermectin in randomized clinical trials with RCT-PCR SARS-CoV-2 clearance, varied from $12 \mathrm{mg}$ daily [6], to $12 \mathrm{mg}$ twice a week [7]. The anti-SARS-CoV-2 actions, both of molnupiravir and ivermectin, are dose and concentration dependent $[1,7]$. Pharmacodynamically, the mechanisms of anti-SARS-CoV-2 action, both of molnupiravir and ivermectin are overlapping and complimentary (Table 1). Molnupiravir active metabolite (NHC-5' Triphosphate), acts as a competitive alternative substrate for the viral RNA dependent RNA polymerase (RdRp), causing viral mutagenesis or transition mutations, which leads to viral error catastrophe and extinction of replication [8]. There is some concern about the safety of NHC -nucleoside triphosphate, which is also mutagenic to mammalian cells [9]. Ivermectin (Table 1) exhibits multifarious actions, ranging from binding to SARS-CoV-2 spike protein S, reducing cell entry via human ACE2 receptors, inhibition of the
Austin J Pharmacol Ther - Volume 9 Issue 5 - 2021

ISSN: 2373-6208 | www.austinpublishinggroup.com Ajayi. (C) All rights are reserved
Citation: Ajayi AAL. Drugs Shown to Inhibit SARS-CoV-2 in COVID-19 Disease: Comparative Basic and Clinical Pharmacology of Molnupiravir and Ivermectin. Austin J Pharmacol Ther. 2021; 9(5).1149. 
Table 1: Comparison of Anti-SARS-CoV-2 pharmacology of Molnupiravir and Ivermectin.

\begin{tabular}{|c|c|c|}
\hline & Molnupiravir & Ivermectin \\
\hline Chemical structure/Name & $\begin{array}{l}\text { RiboNucleoside analogue. Pro-drug of } \beta-d-N^{4} \text { Hydroxycytidine (NHC), } \\
\text { EIDD } 2801\end{array}$ & 22,23 dihydroavermectin $\mathrm{B} 1 \mathrm{a}+\mathrm{B} 1 \mathrm{~b}(80: 20)$ mixture \\
\hline $\begin{array}{l}\text { Pharmacokinetics } \\
\text { Absorption and } F \\
\text { Distribution }\left(\mathrm{V}_{\mathrm{d}}\right) \\
\text { Metabolism } \\
\text { Excretion routes } \\
\mathrm{T} 1 / 2 \text { (hours) } \\
\text { Mean Residence Time (hours) } \\
\text { Tmax (hours) } \\
\text { Daily doses } \\
\text { SARS-CoV2 } \mathrm{IC}_{50}\end{array}$ & $\begin{array}{l}\text { Rapid } \\
\text { Prodrug > EIDD1931 (plasma esterases) > active 5'ATP EIDD (tissue } \\
\text { kinases). } \\
7 \text { hours } \\
? \\
1-1.75 \text { hours } \\
2 \\
0.3 \mu \mathrm{M} \text { (Vero cells) } 0.08 \mu \mathrm{M} \text { (Calu cells) } \\
414.6 \mathrm{nM} \text { (Syrian Hamster) }\end{array}$ & $\begin{array}{l}\text { Good } \\
\text { 9-12L/Kg } \\
\text { Hepatic CYP3A4 mainly, 3A5, 2C9, 2D6 } \\
\text { Fecal >99\% } \\
81-91 \text { hours } \\
84 \text { hours } \\
5 \text { hours } \\
1 \\
\text { 2.5-2-8 } \mu \text { M (E, RdRP cell associated virus genes) } \\
\text { Vero-h/SLAB }\end{array}$ \\
\hline $\begin{array}{l}\text { Pharmacodynamics } \\
\text { Antiviral mechanisms } \\
\text { - Cell viral entry-hACE2 } \\
\text { receptor. }\end{array}$ & 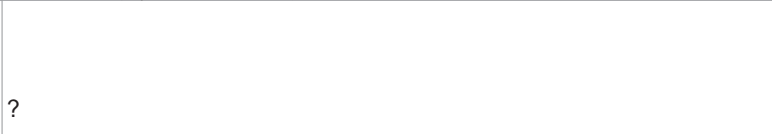 & $\begin{array}{l}\text { Binds to active sites of spike protein S. Inhibits } \\
\text { human cell entrance of virus via h-ACE2. }\end{array}$ \\
\hline $\begin{array}{l}\text { Nuclear transport -importin } \\
\alpha / \beta 1\end{array}$ & $?$ & $\begin{array}{l}\text { Binds Importin } \alpha \text { to prevent link with } \beta 1 \text { and nuclear } \\
\text { transport of viral and host proteins. }\end{array}$ \\
\hline $\begin{array}{l}\text { - RNA dependent, RNA } \\
\text { polymerase (RdRp) }\end{array}$ & $\begin{array}{l}\text { Competitive alternative substrate for SARS-CoV-2 RdRP viral genome } \\
\text { > excessive mutations > viral error catastrophe > viral extinction. }\end{array}$ & $\begin{array}{l}\text { Binds to and inhibits viral RdRp replication and } \\
\text { transcription complex with }-9.7 \mathrm{Kcal} / \mathrm{mol} \text { energy }\end{array}$ \\
\hline Viral mutagenesis & 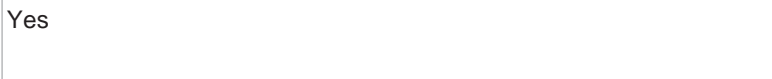 & No \\
\hline $\begin{array}{l}\text { Dose/Concentration-anti SARS- } \\
\text { CoV-2 response }\end{array}$ & Dose -Dependent Viral RNA clearance in human phase 2A study. & $\begin{array}{l}\text { Significant dose and concentration dependent } \\
\text { virucidal response seen in humans. }\end{array}$ \\
\hline $\begin{array}{l}\text { Effects on Cytokines \& } \\
\text { interleukins (IL) }\end{array}$ & $?$ & $\begin{array}{l}\text { Inhibits Janus Kinase (JAK) Signal transduction } \\
\text { Activator of Transcription (STAT-3) and IL-6/10 }\end{array}$ \\
\hline $\begin{array}{l}\text { Clinical Trials and Real World } \\
\text { Efficacy } \\
\text { RT-PCR Cases }\end{array}$ & $\begin{array}{l}\text { Phase } 2 \text { A shows dose dependent high anti-SARS-CoV-2 efficacy in } \\
\text { COVID-19. }\end{array}$ & $\begin{array}{l}\text { Mixed outcomes. Meta-analyses show clinical and } \\
\text { laboratory benefits and mortality reduction. }\end{array}$ \\
\hline $\begin{array}{l}\text { Adverse effects and Drug-Drug } \\
\text { Interactions }\end{array}$ & No Serious Adverse effects compared to placebo. & No Serious Adverse Effects. Dizziness \\
\hline
\end{tabular}

nuclear transport of viral proteins, which prevents interference with replication, to binding to RdRP, reducing the activity of the viral transcription -replication complex [10]. Ivermectin has additional effects on Signal Transduction Activation of Transcription (STAT-3) and inhibition of cytokine production and inflammation, which has not yet been shown for molnupiravir.

As most but not all double blind studies, and meta-analyses, have shown benefits of ivermectin in COVID19 including 56\% mortality reduction [11], and given the complimentary pharmacokinetics and pharmacodynamics of the drugs, direct head -to -head comparison of molnupiravir and ivermectin, in blinded randomized clinical trials are needed. A combination of molnupiravir with Ivermectin putatively, may be at least additive or synergistic in effects on RdRP or cytokine release. This should be further investigated in anti-SARS$\mathrm{CoV}-2$ antiviral combination therapy.

\section{References}

1. Painter WP, Holman W, Bush JA, Almazedi F, Malik H, Eraut CJEN, et al. Human safety, tolerability, and pharmacokinetics of Molnupiravir, A novel broad- spectrum oral antiviral agent with activity against SARS-CoV-2. Antimicrob Angents Chemother. 2021; 65: e02428-e02520.

2. Caly L, Druce JD, Catton MG, Jans DA, Wagstaff KM. The FDA -approved drug ivermectin inhibits the replication of SARS-CoV-2 in vitro. Antiviral Res. 2020.

3. Sheahan TP, Sims AC, Zhou S, Graham RL, Pruijsssers AJ, Agostini ML et al. An orally bioavailable broad-spectrum antiviral inhibits SARS-CoV-2 in human airway epithelial cell cultures and multiple corona viruses in mice. Sci Trans Med. 2020; 12: eabb5883.

4. Munoz J, Ballester MR, Antonijoan RM, Gich I, Rodriguez M, Colli E, et al. Safety and pharmacokinetic profile of fixed dose ivermectin with an innovative $18 \mathrm{mg}$ tablet in healthy adult volunteers. PLoS Negl Trop Dis. 2018; 12: e0006020.

5. Duthaler U, Suenderhauf C, Karlsson MO, Hussner J, Schwabedissen HMZ, Krahenbull S, et al. Population pharmacokinetics of oral ivermectin in venous plasma and dried blood spots in healthy volunteers. Br J Clin Pharmacol. 2019; 85: 626-633.

6. Elgazzar A, Hany B, Yousef SA, Hafez M, Moussa H. Efficacy and safety of ivermectin for treatment and prophylaxis of COVID-19 pandemic in Egypt. 2020.

7. Babalola OE, Bode CO, Ajayi AA, Alakaloko FM, Akase IE, Otrofanowei E, et al. Ivermectin shows clinical benefits in mild to moderate COVID-19: A randomized controlled, double blind, dose response study in Lagos. QJM An international Journal of Medicine. 2021.

8. Wahl A, Gralinski LE, Johnson CE, Yao W, Kavarova M, Dinnon $3^{\text {rd }} \mathrm{KH}$, et al. SARS-CoV-2 is effectively treated and prevented by EIDD-2801. Nature. 2021; 591: 451-457. 
9. Zhou S, Hill CS, Sarkar S, Tse LV, Woodburn BMD, Schinazi RF, et al. $\beta-D-$ $\mathrm{N} 4-\mathrm{Hydroxycytidine}(\mathrm{NHC})$ inhibits SARS-CoV-2 through lethal mutagenesis, but is also mutagenic to mammalian cells. J Infect Dis. 2021.

10. Zaidi AK, Deghani-Mobaraki P. The mechanisms of action of ivermectin against SARS-CoV-2: An evidence -based clinical review article. J Antibiot. 2021
11. Hill A, Garrat A, Levi J, Falconer J, Ellis L, McCann K, et al. Meta-analysis of randomized trials of ivermectin to treat SARS-CoV-2 infection. Open Forum Infectious Diseases. 2021. 